\title{
BEHAVIOUR OF FIBRE-BASED POLYMER CONCRETE SUBJECTED TO AMBIENT AND HEAT CURING
}

\author{
OBNAŠANJE POLIMERNEGA BETONA, OJAČANEGA Z VLAKNI \\ IN IZPOSTAVLJENEGA OBDELAVI NA SOBNI IN POVIŠANI \\ TEMPERATURI
}

\author{
Cherupillil Govindhan Deepanraj*, Rajkumar Veeran \\ Government College of Engineering, Karppur Salem 636 011, Tamil Nadu - 636 011, India \\ Prejem rokopisa - received: 2019-07-07; sprejem za objavo - accepted for publication: 2019-02-12
}

doi:10.17222/mit.2019.143

\begin{abstract}
This paper focuses on the important role of water-bearing factors in mineral-based concrete composites activated by alkali solution and also the function of fibre in draining the water molecules that are formed as the end product of the polymerization process in geopolymer concrete. Polymer-made concrete is found to be more stable than normal concrete in all aspects. The reason that research states in the application of geopolymer concrete is its initial set. Normally, geopolymer concrete takes more than three hours to attain its initial set. Strength attainment is made by applying advanced curing methods. Concrete made with an alkali-activated polymerization process remains fresh even up to four days in ambient curing. An investigation has been made to measure the water discharged after the polymerization process. Draining the discharged water in this study is made by using fibres. In this investigation the geopolymer concrete is admitted to two types of curing, i.e., the ambient and heat modes. The reversibility and retentivity of the water are the factors that relate to the amount of discharged water with its early age properties. The results confirmed that fibres of a $1 \%$ fraction were useful in increasing the draining property and early age weight attainment effectively.
\end{abstract}

Keywords: geopolymer concrete, fibres, curing, water-bearing factors

V članku se avtorji osredotočajo na opis pomembnih zakonov vpliva vsebnosti vode v mineralnem betonskem kompozitu, aktiviranem $\mathrm{z}$ alkalno raztopino in prav tako na delovanje vlaken med odvajanjem vodnih molekul $\mathrm{v}$ končnem izdelku polimerizacijskega procesa izdelave geopolimernega betona. Avtorji ugotavljajo, da je polimerni beton v vseh pogledih bolj stabilen kot normalni (standardni) beton. Razlog, da raziskovalci omahujejo pri uporabi geopolimernega betona je v njegovi začetni fazi. Normalni geopolimerni beton potrebuje namreč več kot tri ure, da doseže svoje začetno (uporabno) stanje. Ustrezno trdnost geopolimernega betona dosežemo le z naprednimi postopki njegove obdelave. Beton, narejen z alkalno aktiviranim procesom polimerizacije, ostane svež celo do štiri dni pri sobni temperaturi obdelave. Avtorji so ugotavljali kakšni naj bi bili postopki za odstranitev vode po procesu polimerizacije. Odvajanje vode v študiji je bilo izvedeno s pomočjo vlaken. V raziskavi geopolimernega betona so avtorji uporabili dve vrsti obdelave, t.i. pristop pri sobni in pristop pri povišani temperaturi. Reverzibilnost in ohranjanje vode sta dva faktorja izvornih lastnost betona, ki sta odvisna od vsebnosti odstranjene vode. Rezultati raziskave kažejo, da dodatek enega procenta (1\%) vlaken ugodno vpliva na pospeševanje sušenja in že zelo zgodaj učinkovito dosežemo ustrezne lastnosti betona.

Ključne besede: geopolimerni beton, vlakna, obdelava, faktorji obrabe

\section{INTRODUCTION}

Alkali-activated concrete has advantages over conventional concrete in major aspects, such as low $\mathrm{CO}_{2}$ emission, strength and durability. The only disadvantage found with geopolymer concrete is the time taken for its initial set, which results after the polymerization process. It is well known that alkali-activated geopolymer concrete needs a greater time in its setting. This is due to the presence of water molecules inside the concrete mass. The water molecules resulting after the polymerization process makes the concrete green for a long period. The water molecules move towards the open portion of the mould and are evaporated. The anti-gravitation movement of the water molecules from the concrete slow the polymerization process in concrete. A quick remedy in

*Corresponding author's e-mail:

deepancdhassini@gmail.com (Deepanraj C.G.) expelling the water from the GPC is oven curing in order to decrease the time for the initial set.

This experiment involves the draining of water molecules from the wet concrete, thereby decreasing the time of the initial set and speeds up the weight attainment. The addition of polypropylene fibres into the concrete makes the concrete drain water molecules much more quickly. To attain the initial set, the specimens are subjected to ambient and heat dry modes to attain it full weight. This investigation is about the initial level of processing i.e., from its cast before the curing.

The end products resulting from the polymerization process are given in Figure 1.

The complimentary component water formed during the end product of the polymerization process needs to expel the concrete to make it set faster. This study is an attempt to measure the quantity of drained water molecules from the concrete. A special test setup has been 


$$
\begin{array}{cc}
(\mathrm{Na}+, \mathrm{K}+)-(\mathrm{Si}-\mathrm{O}-\mathrm{Al}-\mathrm{O}-\mathrm{Si}-\mathrm{O}- & +\mathrm{n}(\text { Water }) \\
\text { I } & \text { II } \\
\text { O } & \text { OO }
\end{array}
$$

Figure 1: End product of polymerization process

made for measuring the resulting water. A different fibre fraction, namely, $0.5 \%, 1 \%$ and $1.5 \%$, are added to the mix and the optimization was made on the concentrations with the mechanical property, and an optimum fibre was produced to study its significance in the effective draining of the water from the concrete mix.

\section{EXPERIMENTAL PART AND METHODOLOGY}

The basic methodology is to experiment the role of fibers in draining out the water from:

Step 1: material study

Step 2: methods

Step 3: testing

Step 4: evaluation of results

Step 5: conclusion

\section{MATERIAL STUDY}

\subsection{Fly ash}

Fly ash of Class-F type was used as the source material, which is enriched with silica and alumina, and the specific gravity is 3.12 .

\subsection{Fine aggregate (FA)}

Clean river sand free of impurities passing through a $4.75 \mathrm{~mm}$ sieve and retained on a 60-micron sieve with a fineness modulus of 3.11 and a specific gravity of 2.64 was used for the study.

\subsection{Coarse aggregate (CA)}

12-mm coarse aggregate was used for the present study. The physical properties of the coarse aggregate are tested as per IS2386-1963. The specific gravity of the coarse aggregate is 2.36 and its impact value is $4.62 \%$.

\subsection{Water}

Potable water available in the laboratory, which fulfils the needs as per IS 456:2000, was used to make the sodium hydroxide solution

\subsection{Sodium hydroxide solution $(\mathrm{NaOH})$}

Sodium hydroxide flakes of specific gravity 1.44 were used to make the solution with a 12-molar concentration.

\subsection{Sodium silicate solution $\left(\mathrm{Na}_{2} \mathrm{SiO}_{3}\right)$}

Sodium silicate solution of $99 \%$ purity with specific gravity 1.52 was used for the present study.

\section{3-P.7 lypropylene fibres (PPF)}

Low-density and acid-resistant 12-mm length polypropylene fibres with an aspect ratio of 60 were used.

\section{METHODS}

\subsection{Alkaline activator solution}

In the preparation of the sodium hydroxide solution, sodium hydroxide flakes were mixed with water, which liberates heat when it reacts with water. Since the activator solution; a mixture of sodium hydroxide solution and sodium silicate was prepared one day prior to the day of the cast.

\subsection{Mix design and designation}

The design mix for the M35 grade was made as per the modified guidelines and the quantity of the

\begin{tabular}{|c|c|c|c|c|c|c|}
\hline Fly Ash & $\mathrm{NaOH}$ & $\mathrm{Na}_{2} \mathrm{SiO}_{3}$ & FA & CA & PPF & Water \\
\hline $\begin{array}{c}600 \\
\mathrm{~kg} / \mathrm{m}^{3}\end{array}$ & $\begin{array}{c}39 \\
\mathrm{~kg} / \mathrm{m}^{3}\end{array}$ & $\begin{array}{c}265 \\
\mathrm{~kg} / \mathrm{m}^{3}\end{array}$ & $\begin{array}{c}584 \\
\mathrm{~kg} / \mathrm{m}^{3}\end{array}$ & $\begin{array}{c}734 \\
\mathrm{~kg} / \mathrm{m}^{3}\end{array}$ & $\begin{array}{c}6 \\
\mathrm{~kg} / \mathrm{m}^{3}\end{array}$ & $\begin{array}{c}68 \\
\mathrm{~kg} / \mathrm{m}^{3}\end{array}$ \\
\hline 1 & 0.065 & 0.442 & 0.973 & 1.223 & 0.01 & 0.113 \\
\hline
\end{tabular}
ingredients is indicated below in Table $\mathbf{1}$.

Table 1: Mix of ingredients and ratios

Mix designation: AMNF - ambient mode with no fibre AMF - ambient mode with $1 \%$ fibre concentration HMNF - heat mode with no fibre HMF - heat mode with $1 \%$ fibre concentration

\subsection{Mode}

Curing was one of the synthesizing parameters which progress the strength of the geopolymer concrete. To synthesize geopolymer specimens, curing were adapted. Two types of curing mode were adapted for the present study:

1) ambient mode - room temperature $\left(30^{\circ} \mathrm{C}\right)$, and

2) heat mode $\left(80^{\circ} \mathrm{C}\right)$. The initial set also depends on the processing parameters, such as the ratio between the hydroxides and the silicates, the molarity of the hydroxides etc. The initial set starts after the polymerization process occurs.

\subsection{Mixing}

Fly ash, fine aggregate, and coarse aggregate were mixed dry with and without fibres. After the dry mixing, the activator solution is mixed with the dry mass and cast in a mould of size $100 \mathrm{~mm} \times 100 \mathrm{~mm} \times 100 \mathrm{~mm}$ cube. After the cast the cubes with and without fibres are placed in the ambient and heat modes for study. 

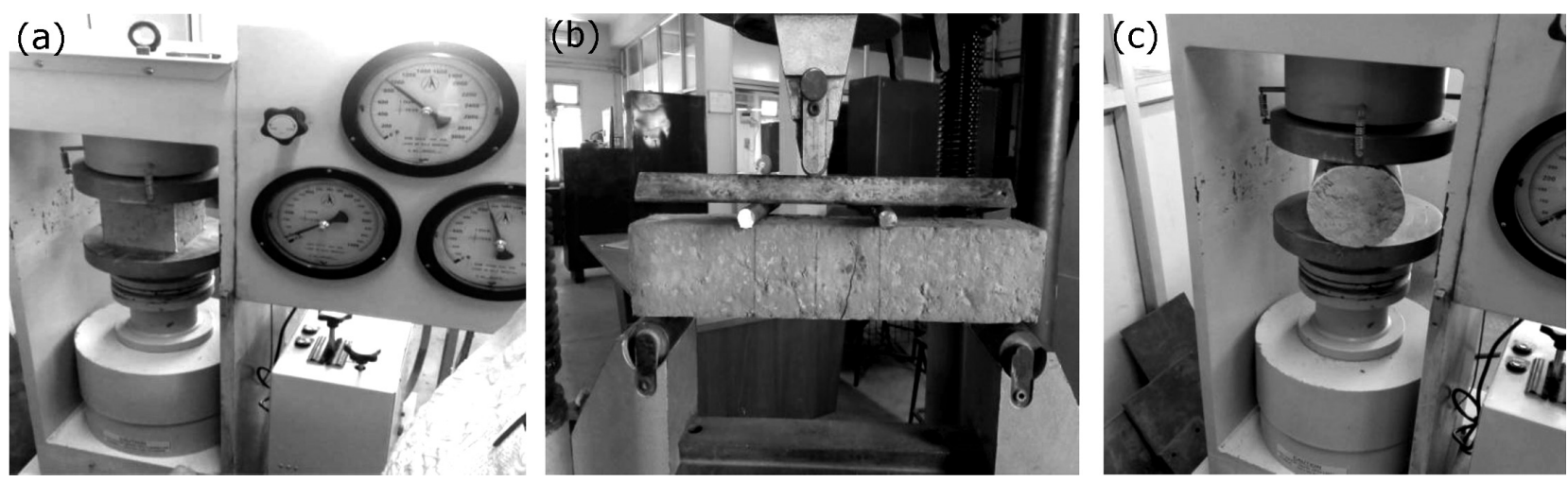

Figure 2: a) Compressive strength test, b) flexural test, c) split tensile test

\subsection{Duration of the mode}

It was observed that the initial set of the geopolymer concrete was $210 \mathrm{~min}$; hence in the case of the ambient mode the tests are conducted after its initial set (210 min). In the case of the heat mode, the specimens are kept under heat for $120 \mathrm{~min}$. After $120 \mathrm{~min}$ the concrete was ready for the test.

\subsection{Mechanical test}

Different fibre fractions were mixed into the concrete to find the optimum fibre fraction from the mechanical performance for the detailed investigation towards the measurement of the water-bearing factors. The optimization was carried out for the fibre fractions of $0.5 \%, 1 \%$ and $1.5 \%$. The optimum fibre fraction was considered for the measurement of the reversibility and retaintivity. The tests are shown in Figure 2.

\subsection{Experimental setup}

An experimental setup was made for measuring the discharge from the concrete mix, which is indicated in
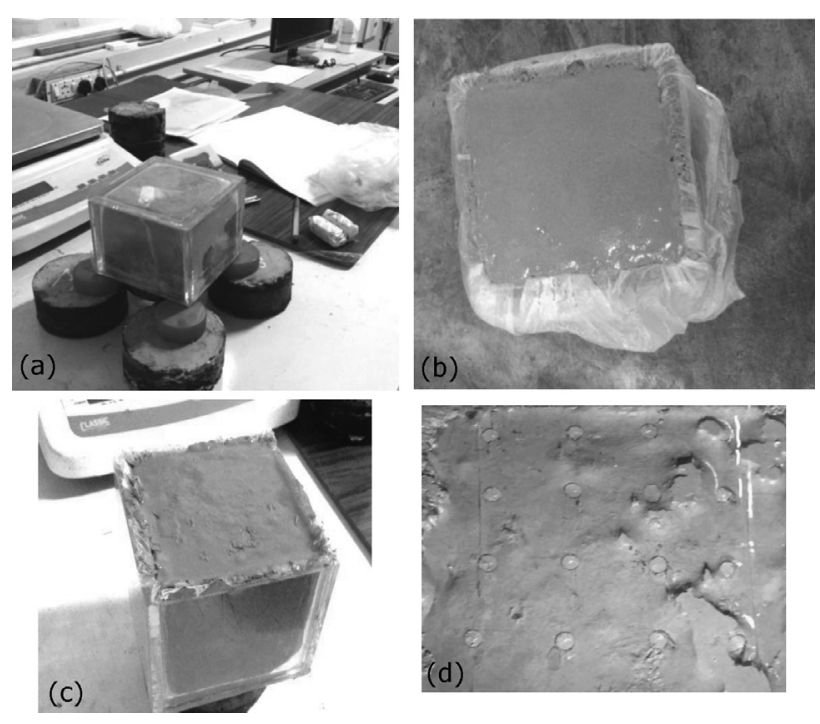

Figure 3: a) Experimental set up, b) concrete at fresh stage, c) concrete after initial set, d) perforated plastic sheet on concrete
Figure 3. The cube mould of $100 \mathrm{~mm}$ was made using glass panels, which was open at its base. Porous stone of 100 -mm diameter was placed at the base of the mould, right below the concrete surface. The whole setup was kept inside a glass container to exclude the room conditions, since the water expelled can be absorbed due to there being less humidity in air. A thin film of perforated polythene sheet was placed between the concrete and porous stones, which act as the filter media.

\subsection{Sizing of perforations}

The fresh concrete was used to find the correct perforation diameter. Perforations of diameter $3 \mathrm{~mm}, 4 \mathrm{~mm}$ and $5 \mathrm{~mm}$ were checked with the fresh concrete. In the 3-mm diameter perforations the fresh concrete found it very difficult to expel the processed water. The surface tension was higher, thereby draining the water was found to be impossible. In the 5-mm diameter perforations, the concrete slurry came out since a larger diameter made the concrete pump out. The 4-mm diameter perforations drained the processed water from the concrete.

\subsection{Testing}

Fresh concrete was kept in the test set-up. The curing modes were applied for each specimen. The difference in the initial and final weights of the porous stone led to the water being discharged over a period of time. The testing was carried out until the final discharge was reached. The discharged water with the corresponding time in hours was noted. Different stages of the concrete and the expelled water molecules are studied in details.

\subsection{Reversibility}

Reversibility is defined as the ratio of added water to make the concrete to the processed water after the polymerization process from the concrete. Water added while preparing the $\mathrm{NaOH}$ solution was considered. The water was mixed with $\mathrm{NaOH}$ flakes. The water that was processed was measured by test set up. This property indicates the reversed quantity of water from the concrete. 


\subsection{Retain property}

Retentivity is defined as the percentage of concrete to withhold the water within it. Retentivity is inversely related to the drainage ability. Until the polymerization process, the water will be in an unprocessed form, which was withheld by the concrete matrix. Perforations drain the processed water from the concrete, thereby reducing the retaining capacity of the concrete.

\section{RESULTS AND DISCUSSIONS}

\subsection{Mechanical properties}

Different percentage of fibre concentrations were optimized based on the mechanical properties. Tables 2 to $\mathbf{5}$ indicate the different strength properties of the geopolymer concrete specimens with the mentioned fibre fraction under the ambient and heat modes. The results concluded that the geopolymer specimens with the fibre fraction of $1 \%$ recorded the maximum values.

Table 2: Compressive strength of GPC specimens under ambient curing

\begin{tabular}{|c|c|c|c|}
\hline \multirow{2}{*}{ Description } & \multicolumn{3}{|c|}{ Compressive strength $\left(\mathrm{N} / \mathrm{mm}^{2}\right)$ at } \\
\cline { 2 - 4 } & $3 \mathrm{~d}$ & $7 \mathrm{~d}$ & $28 \mathrm{~d}$ \\
\hline $\mathrm{GPC}$ & 10.42 & 21.27 & 33.27 \\
\hline $\mathrm{GPC}^{1}$ & 24.48 & 36.22 & 52.41 \\
\hline $\mathrm{GPC}^{2}$ & 28.82 & 38.58 & 54.77 \\
\hline $\mathrm{GPC}^{3}$ & 22.32 & 31.18 & 38.56 \\
\hline
\end{tabular}

GPC- geopolymer concrete with $0 \%$ of fibre fraction $\mathrm{GPC}^{1}$ - geopolymer concrete with $0.5 \%$ of fibre fraction $\mathrm{GPC}^{2}$ - geopolymer concrete with $1 \%$ of fibre fraction $\mathrm{GPC}^{3}$ - geopolymer concrete with $1.5 \%$ of fibre fraction

Table 3: Compressive strength of GPC specimens under heat curing

\begin{tabular}{|c|c|c|c|}
\hline \multirow{2}{*}{ Description } & \multicolumn{3}{|c|}{ Compressive strength $\left(\mathrm{N} / \mathrm{mm}^{2}\right)$ at } \\
\cline { 2 - 4 } & $3 \mathrm{~d}$ & $7 \mathrm{~d}$ & $28 \mathrm{~d}$ \\
\hline $\mathrm{GPC}$ & 13.26 & 25.28 & 34.79 \\
\hline $\mathrm{GPC}^{1}$ & 28.35 & 44.12 & 61.23 \\
\hline $\mathrm{GPC}^{2}$ & 34.22 & 44.26 & 65.91 \\
\hline $\mathrm{GPC}^{3}$ & 24.16 & 35.68 & 41.12 \\
\hline
\end{tabular}

Table 4: Flexural strength of GPC Specimens under ambient and heat modes

\begin{tabular}{|c|c|c|c|c|}
\hline \multirow{2}{*}{ Description } & \multicolumn{4}{|c|}{ Flexural strength $\left(\mathrm{N} / \mathrm{mm}^{2}\right)$ at } \\
\cline { 2 - 5 } & \multicolumn{2}{|c|}{ Ambient mode } & \multicolumn{2}{c|}{ Heat mode } \\
\cline { 2 - 5 } & $7 \mathrm{~d}$ & $28 \mathrm{~d}$ & $7 \mathrm{~d}$ & $28 \mathrm{~d}$ \\
\hline GPC & 2.58 & 3.88 & 3.59 & 4.01 \\
\hline $\mathrm{GPC}^{1}$ & 3.22 & 5.27 & 3.98 & 6.83 \\
\hline $\mathrm{GPC}^{2}$ & 4.32 & 6.14 & 5.81 & 7.69 \\
\hline $\mathrm{GPC}^{3}$ & 3.02 & 3.27 & 3.72 & 3.66 \\
\hline
\end{tabular}

Table 5: Split strength of GPC specimens under ambient and heat modes

\begin{tabular}{|c|c|c|c|c|}
\hline \multirow{2}{*}{ Description } & \multicolumn{4}{|c|}{ Split tensile strength $\left(\mathrm{N} / \mathrm{mm}^{2}\right)$ at } \\
\cline { 2 - 5 } & \multicolumn{2}{|c|}{ Ambient mode } & \multicolumn{2}{c|}{ Heat mode } \\
\cline { 2 - 5 } & $7 \mathrm{~d}$ & $28 \mathrm{~d}$ & $7 \mathrm{~d}$ & $28 \mathrm{~d}$ \\
\hline GPC & 1.04 & 2.23 & 1.17 & 2.76 \\
\hline GPC $^{1}$ & 1.14 & 2.31 & 1.26 & 2.82 \\
\hline GPC $^{2}$ & 1.19 & 2.46 & 1.38 & 2.92 \\
\hline GPC $^{3}$ & 1.13 & 2.28 & 1.31 & 2.87 \\
\hline
\end{tabular}

\subsection{Reversibility}

Figure 4 shows the time vs coefficient of reversibility for the specimens with and without the fibre under ambient and heat modes of curing.

AMNF shows a faster rate of discharge found during the last segment (37-52 h). In AMF the rate of discharge was found to be faster from the $12^{\text {th }}$ hour itself and it continues in a constant rate until its final expulsion. Fibres in AMF specimens proved to have a better drainage capacity than that of the non-fibre-based specimens.

In HMNF the activation of the polymerization process was initiated by the application of heat. It showed a faster rate of water expulsion from the initial stage itself. The HMF specimens showed a better expulsion rate when compared to the HMNF specimens. The maximum coefficient of reversibility was found in the HMF specimens, which infer that the fibres in the heat mode of the initial set perform better in terms of draining the water than all the other specimens.

The fibres, when mixed with the geopolymer concrete in both the curing modes, improve the draining capability more than that of the normal geopolymer concrete.

\subsection{Retentivity}

The retaining capacity of the AMNF specimens indicated in Figure $\mathbf{5}$ showed the retentivity was still good in its $9^{\text {th }}$ hour, while from the $9^{\text {th }}$ hour to the $33^{\text {rd }}$ hour the retentivity was reduced by $31.24 \%$, and a heavier loss of retentivity was observed from the period of the $33^{\text {rd }}$ hour

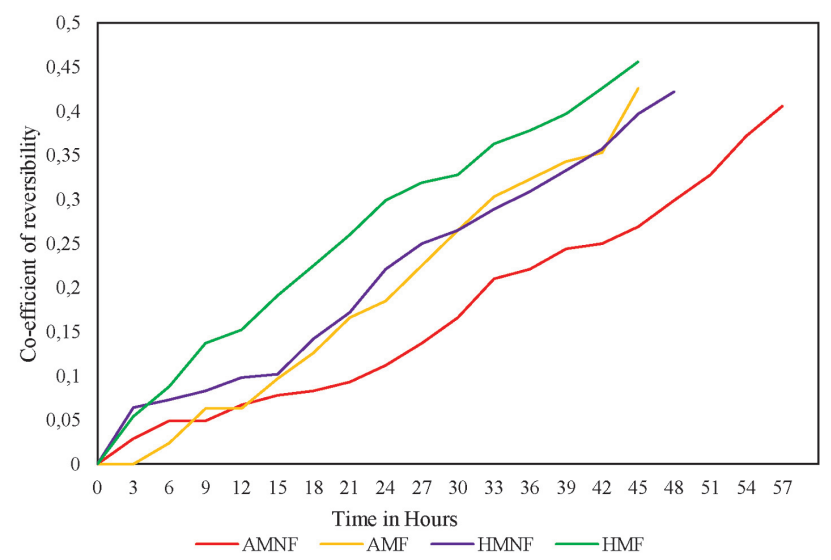

Figure 4: Time vs. coefficient of reversibility 

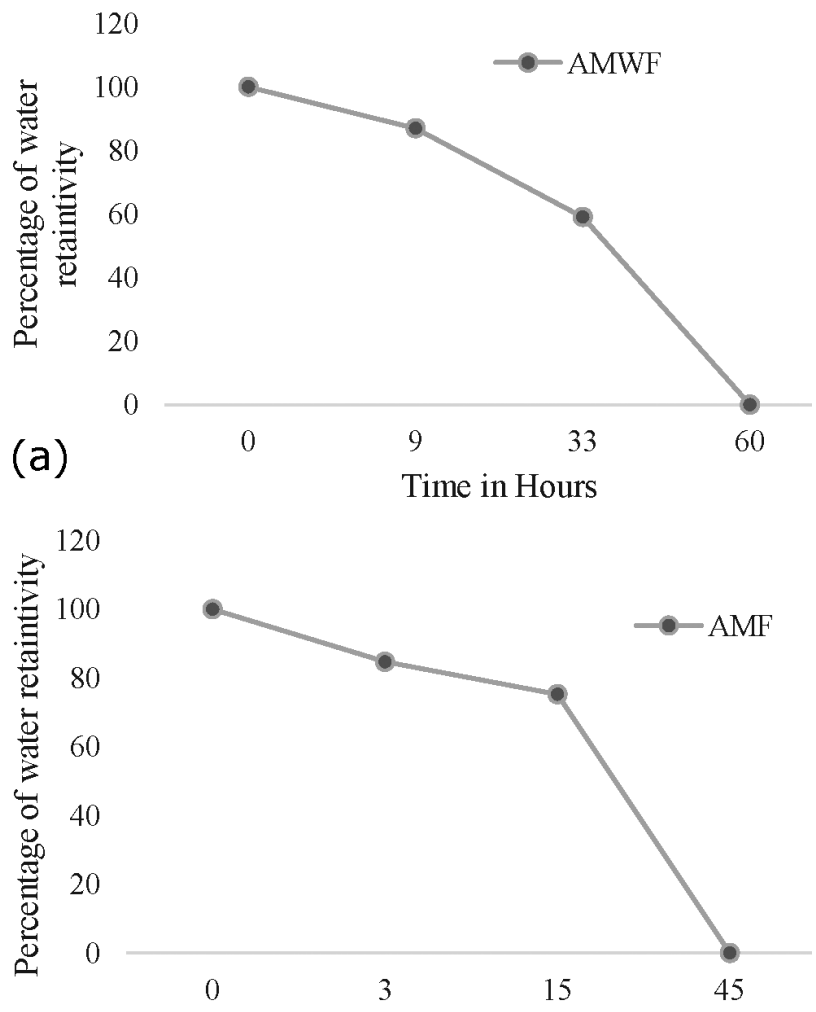

(b)

Time in Hours

Figure 5: Water retentivity in \% for the specimens: a) without fibre, b) with fibre under ambient mode
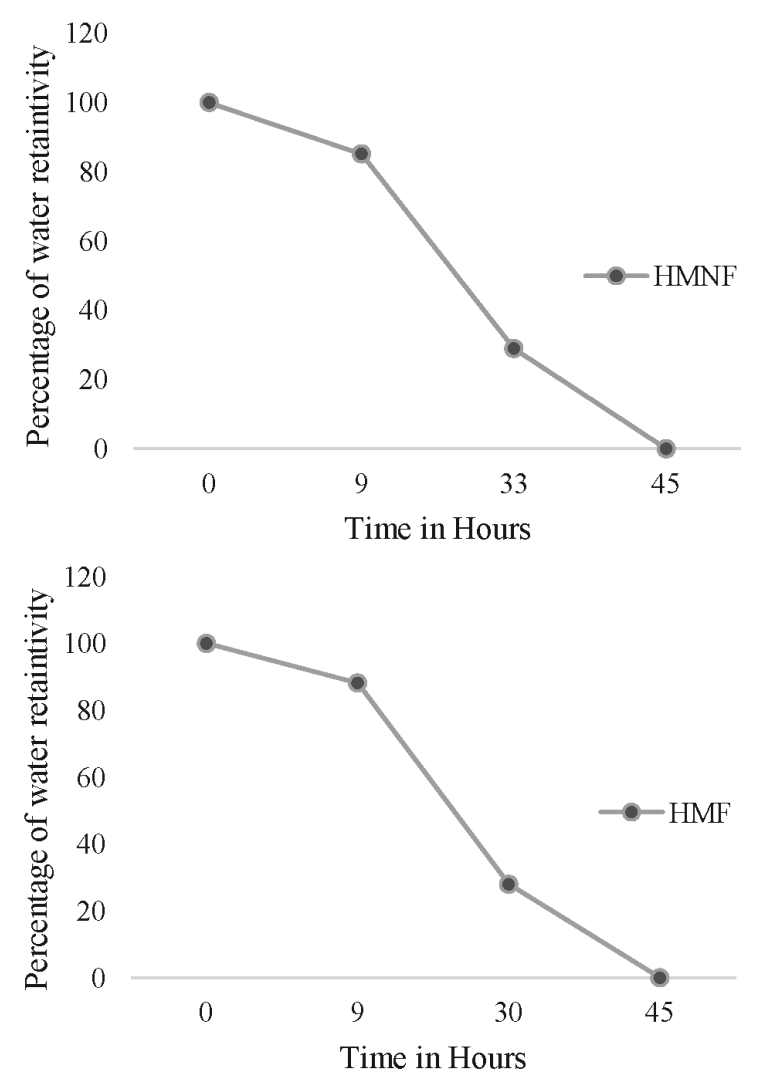

Figure 6: Water retentivity in $\%$ for the specimens: a) without fibre and $b$ ) with fibre under heat mode to the $60^{\text {th }}$ hour and recorded as $59.1 \%$. From the results it can be seen that the retentivity loss occurred during the last stage of its setting, which indicates that the AMNF specimens had the best retentivity of all the specimens. Retentivity was indirectly related to the setting time of the concrete: the higher the retentivity the shorter the setting time of the GPC specimens. In the case of AMF specimens, the retentivity was good up to $3^{\text {rd }}$ hour. After that the fibres played a major role in breaking the retentivity of the concrete to hold the water within it. The loss in the retentivity was found to be $9.5 \%$ up to $12 \mathrm{~h}$. A steep loss in retentivity was observed from the $15^{\text {th }}$ to the $45^{\text {th }}$ hour and observed as $75.2 \%$. The loss of retentivity was higher when compared with the AMF specimens. The fibre-based specimen broke the retentivity of the concrete, thereby making the concrete set faster. The HMNF specimens started to break their retentivity at the $9^{\text {th }}$ hour; this may be due to the application of heat. The loss in retentiveness was found to be $56.21 \%$ at the $33^{\text {rd }}$ hour. At the end of the $45^{\text {th }}$ hour it was observed as $28.96 \%$. This retentivity loss was observed during the second phase of setting. Only a lesser percentage of loss was observed during the last phase of the concrete setting. HMF specimens showed the loss of retentivity at the $9^{\text {th }}$ hour. This was same as that of the HMNF specimens, but $11.84 \%$ was observed. After $45^{\text {th }}$ hour it was observed as $28 \%$. It was clear that the specimens set during the second phase. A rapid rate of decrease in the retentivity of the specimen was monitored during the $30^{\text {th }}$ hour, indicated in Figure 6. This proved that the fibres made a faster setting of the concrete than without the fibres.

\subsection{Percentage of weight attained}

Figure 7 clearly depicts the average weight attained with respect to time for all the specimens. Figure 8 indicates that the AMNF specimen showed a linear increase in all the zone classification points. (zone

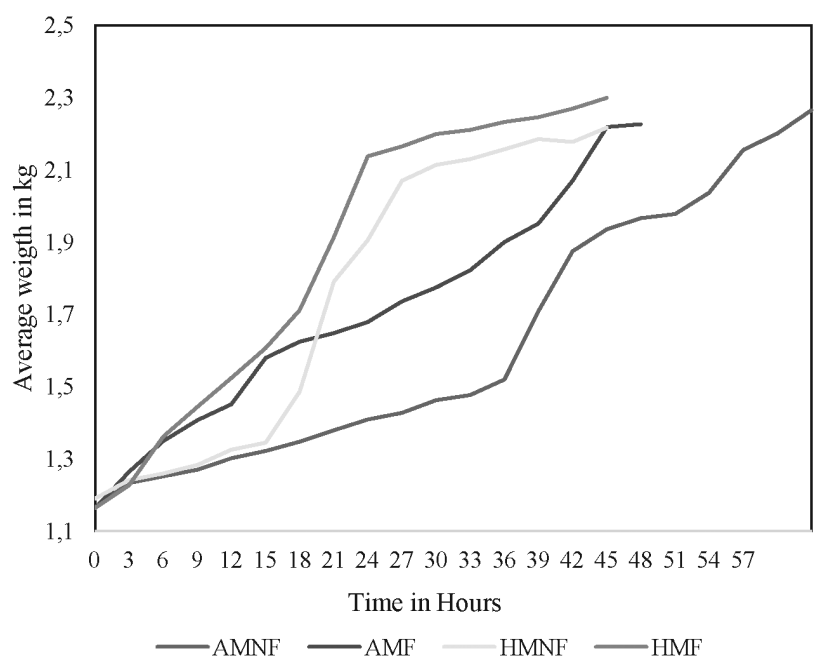

Figure 7: Average weight in $\mathrm{kg}$ vs time in hours 


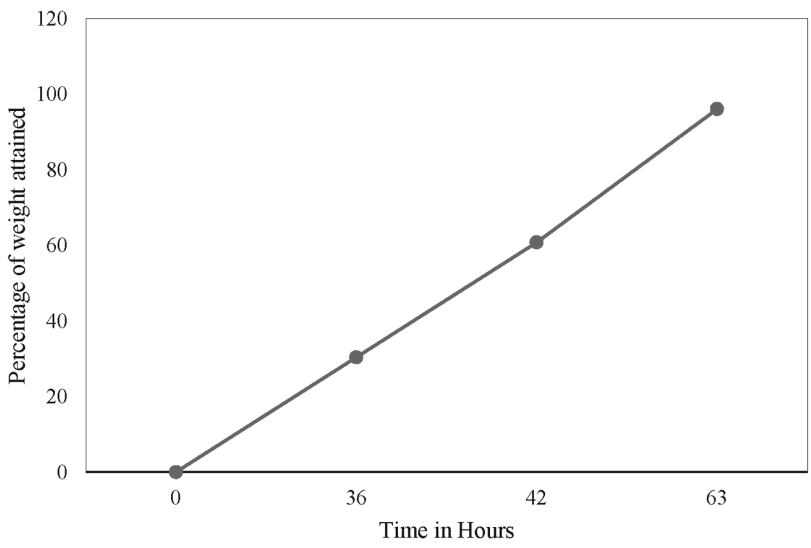

Figure 8: Weight attained in $\%$ vs. time in hours for AMNF specimens

classification points are the points which showed an average out limit of the percentage of weight attained). The weight attained in the AMNF specimen was found to have a direct relationship with time.

Figure 9 indicates that the AMF specimens showed a rapid transition in weight attained from the $15^{\text {th }}$ to the $27^{\text {th }}$ hour at $60.93 \%$. The addition of fibres drained out water, thereby increasing the set time and increasing the weight of the concrete specimen.

From Figure $\mathbf{1 0}$ it is clear that HMNF specimens exist in three levels of stages in attaining the weight. Until the $15^{\text {th }}$ hour it was $28.06 \%$, which can be under a linear transition zone, from $15^{\text {th }}$ hour to $27^{\text {th }}$ hour lies under a stabilized or steady zone where the weight attained was found to be attained by $11.39 \%$. A rapid transition was found from the $27^{\text {th }}$ hour to the $45^{\text {th }}$ hour for $57.1 \%$, which showed that during the last stage a higher transition occurred.

From Figure 11 the HMF specimens showed a moderate transition until the $6^{\text {th }}$ hour. It was also seen that the fibres made the transition very quick. From the $6^{\text {th }}$ to the $24^{\text {th }}$ hour it was observed $66.67 \%$. A rapid transition occurred at this stage. From the $24^{\text {th }}$ hour to the $45^{\text {th }}$ hour a moderate transition occurred. It showed that the rapid transition zone occurred during the second

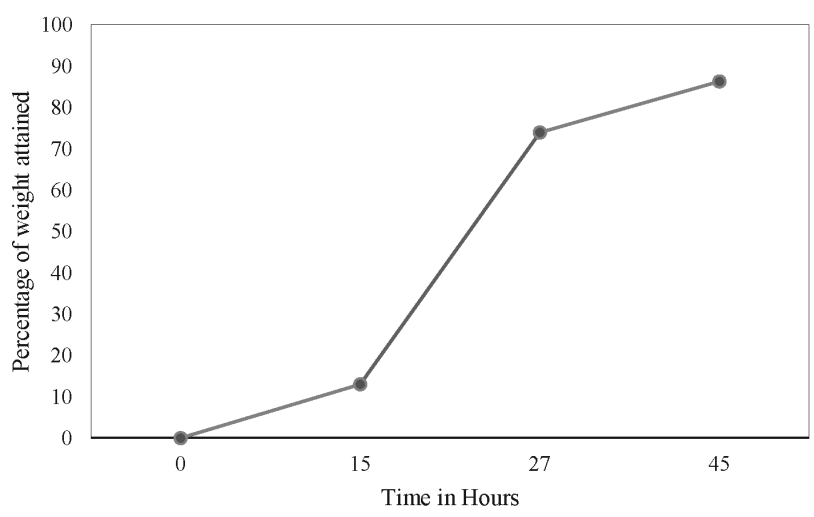

Figure 9: Weight attained in \% vs. time in hours for AMF specimens

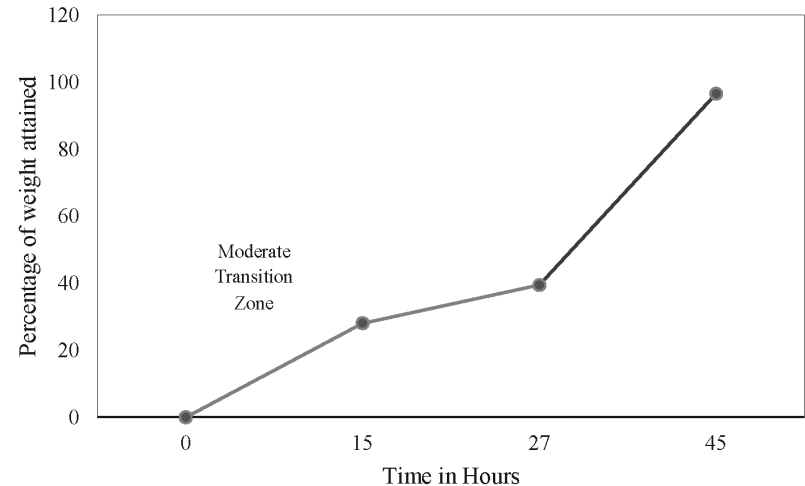

Figure 10: Weight attained in \% vs. time in hours for HMNF specimens

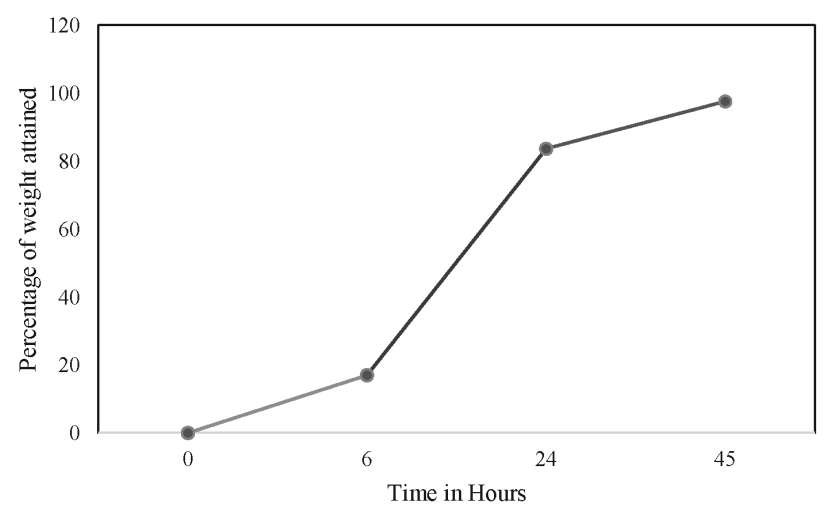

Figure 11: Weight attained in \% vs time in hours for HMF specimens

phase, whereas a moderate transition was observed at the third stage in the HMNF specimens.

\subsection{Microstructural property}

In Figure 12 indicates the even distribution of the fibre inside the concrete matrix. It is also clear, the type of bond it made with the concrete and even with the fibres. The uniform mixing of the fibre inside the concrete makes the concrete perform better and be stable in all environments. The fibres play a major role in enhancing the draining property of the concrete as well.

The concrete with fibres in both modes, i.e., ambient mode and heat mode, after studying the drainage pattern, showed specimens with fibres had a draining path that turned out to be a proof for the draining property of fibre from Figures 12b and 12c. The paths that were formed by the fibres concluded that the fibres arranged themselves in such a path that the water will drain easier and faster. The drain path formed, due to the bottom side of the concrete being kept open. Gravity played a major role in eliminating the water from the concrete. The pictures with fibres also showed that the relations between the resulting water and fibres were good, since the fibres channelled the water to exit the concrete. The fibres rearranged themselves in a pattern such that the water can be eventually expelled from the concrete and thereby easily making the concrete to set quickly. The fibre made 

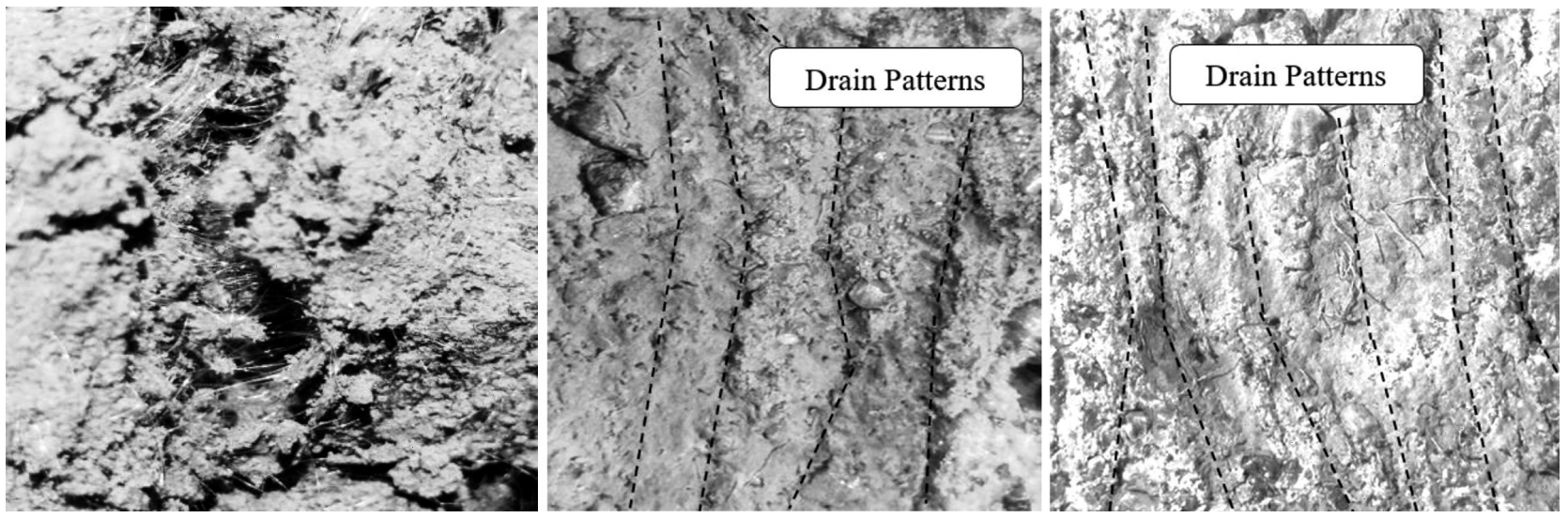

Figure 12: a) Fibre distribution in concrete matrix, b) drain patterns in AMF specimen, c) drain patterns in HMF specimen

the concrete set quickly and get hard. In heat mode, it was observed that with more channels being formed due to application of heat, the fibres were able to rearrange themselves to form the necessary path inside the concrete surface. Thus, it was clear that the fibres pulled out the water from the concrete for improved performance.

\section{CONCLUSIONS}

A fibre fraction of $1 \%$ was effective in all the mechanical tests when compared to other fractions in both the modes: ambient and heat.

AMF specimens showed a higher reversibility coefficient of 0.426 than the AMNF specimens of 0.406

HMF specimens also showed a higher reversibility coefficient of 0.456 than the HMNF specimens of 0.422

AMF breaks the retaining property of the concrete in the third hour, while AMNF specimens break the retentiveness during the ninth hour.

Both HMNF and HMF break the retaining property during the ninth hour, with little variation in its percentages.

A linear transition zone profile is observed for the AMNF, a rapid transition zone profile is observed for the AMF, steadily followed by a rapid transition zone profile for the HMNF, moderately followed by a rapid transition zone profile observed for the HMF specimens.

Drain paths are found in the AMF and HMF specimens, which prove that fibres made the path for draining the water molecules from the concrete specimen.

\section{REFERENCES}

A. Omar, K. Abdul, R. Mahyuddin, Optimizaiton of alkaline activator mixing and curingcondition for a fly ash-based geopolymer paste system, Modern Applied Science, 9 (2015) 12, 61-69, doi:10.5539/ mas.v9n12p61

${ }^{2}$ A. M. Fernandez-Jimenez, A. Palomo, Engineering properties of alkali-activated fly ash cementitious materials, Journal of Material Science, 103 (2006) 2, 106-112

A. R. Krishnaraja, N. P. Sathish kumar, T. Sathish kumar, P. Dinesh kumar, Mechanical behaviour of geopolymer concrete under ambient curing, International Journal of Scientific Engineering and technology, 3 (2014) 2, 130-132

${ }^{4}$ D. Hardjito, E. W. Steenie, M. J. S. Dody, B. V. Rangan, Factors influencing the compressive strength of the fly ash-based geopolymer concrete, Civil Engineering Dimension, 6 (2004) 2, 88-93, doi:10.9744/ced.6.2.pp.\%2088-93.

${ }^{5}$ D. L. Y, Kong, J. G. Sanjayan, Effect of elevated temperatures on geopolymer paste, mortar and concrete, Cement and Concrete Research, 40 (2010) 40, 334-339

${ }^{6}$ D. Rekha, S. K. Sharma, G. Himmi, Effect of different curing conditions on geopolymer concrete by partially replacing sand with foundry sand, Journal of Today's Ideas -Tomorrow's Technologies, 3 (2015) 2, 123-128, doi:10.15415/jotitt.2015.32008

G.S. Ryu, Y.B. Lee, Y.S. Chung, The mechanical properties of fly ash-based geopolymer concrete with alkaline activators, Construction and Building Materials., 47 (2013), 409-418

${ }^{8}$ K. Mythili, C. G. Deepanraj, V. Rajkumar, Calorific studies and its influence on alkali activated fly ash based concrete composites, International Journal of Latest Technology in Engineering, Management \& Applied Science, 7 (2018) 12, 01-06

${ }^{9}$ K. Vijai, R. Kumutha, B. G. Vishnuram., Effect of types of curing on strength of geopolymer concrete, International journal of the Physical Sciences, 5 (2010) 9, 1419-1423

${ }^{10}$ K. T. Robin, K. Ankush, A brief review on geopolymer concrete, International Journal of Advanced Research in Education Technology, 2 (2015) 3, 70-73

${ }^{11}$ L. H. Sandeep, R. M. Damgir, S. V. Patankar, State of art - investigation of method of curing on geopolymer concrete, IOSR Journal of Mechanical and Civil Engineering, 12 (2015) 3, 40-44, doi:10.9790/ 1684-12324044

${ }^{12}$ M. Shriram, I. R. Mithanthaya, N. Bhavani Shankar Rao, A review on strength and durability studies on geopolymer concrete, International Journal of Innovative Research in Science, Engineering and Technology, 5 (2016) 9, 917-921, doi:10.15680/IJIRSET.2016. 0505651

${ }^{13}$ M. A. Javeed, K. Veerendra, H. Narendra, Studies on mix design of sustainable geo-polymer concrete, International Journal of Innovative research in Engineering \& management, 2 (2015) 4, 9-14

${ }^{14}$ M. I. Abdul Aleem, P. D. Arumairaj, Geopolymer concrete - a review, International journal of Engineering Sciences \& Emerging Technologies, 1 (2012) 2, 118-122, doi:10.1.1.429.5

${ }^{15}$ M. S. Girawale, Effects of alkaline solution on geopolymer concrete, International Journal of Engineering research and general science., 3 (2015) 4, 848-853

${ }^{16}$ P. Aditya Kumar, C. Manjeet, P. Basanta Kumar, Effect of synthesis parameters on the compressive strength of fly ash based geopolymer concrete, International Journal of Environmental Pollution Control \& Management, 3 (2011) 1, 79-88 


\section{G. DEEPANRAJ, V. RAJKUMAR: BEHAVIOUR OF FIBRE-BASED POLYMER CONCRETE SUBJECTED TO ...}

${ }^{17}$ R. Janani, A. Revathi, Experimental study of geopolymer concrete with manufactured sand, International Journal of Science, Engineering and Technology Research, 4 (2015) 4, 1054-1057

${ }^{18}$ R.N. Thakur, S. Ghosh., Effect of mix composition on compressive strength and microstructure of fly ash based geopolymer composites, ARPN Journal of Engineering and Applied Sciences., 4 (2006) 4 68-74.

${ }^{19}$ R. V. Prakash, V. D. Urmil, Parametric studies on compressive strength of geopolymer concrete, Proceedings of $3^{\text {rd }}$ Nirma University International Conference on Chemical, Civil and Mechanical Engineering, (2013) Ahmedabad, India, December
${ }^{20}$ C. G. Dhinakaran, Effect of hot water curing and hot air oven curing on admixed concrete, International Journal of ChemTech Research, 6 (2014), 1516-1523

${ }^{21}$ S. Ganesh Kumar, M. I. Abdul Aleem, Application of geopolymer concrete, International Research Journal of Engineering and Technology, 2 (2015) 9, 96-99

${ }^{22} \mathrm{~S}$. Kumaravel, Development of various curing effect of nominal strength geopolymer concrete, Journal of Engineering Science and Technology Review, 7 (2014) 1, 116-119

${ }^{23}$ S. V. Joshi, M. S. Kadu, Role of alkaline activator in development of eco-friendly fly ash based geopolymer concrete, International Journal of Environmental Science and Development, 3 (2012) 5, 417-421 